\title{
交流課電下の架橋ポリエチレン中の空間電荷形成
}

\author{
学生員村 田 光一 (武藏工業大学) \\ 正員田中康寛（武蔵工業大学） \\ 正員高田達雄 (武蔵工業大学)
}

\section{Space Charge Formation in Cross-linked Polyethylene under AC Voltage}

\author{
Koichi Murata, Student Member, Yasuhiro Tanaka, Member, \\ Tatsuo Takada, Member (Musashi Institute of Technology)
}

Space charge formation in cross-linked polyethylene (XLPE) under AC voltage application were observed using Pulsed electro-acoustic (PEA) method. To observe the change of the space charge distribution with the changing voltage of $\mathrm{AC}$, a new automatic measurement system with PEA method has been developed. Using the new system, it makes possible to observe the space charge formation at any phase angle of applying $\mathrm{AC}$ voltage. In this report, the frequency dependence from about 0.0002 to $50 \mathrm{~Hz}$ (period $\mathrm{T}=20 \mathrm{~ms} \sim 8($ ) min) on the space charge formation were investigated. Under $\mathrm{AC}$ voltage stress with long period $(\mathrm{T}=40$ and $80 \mathrm{~min})$, the accumulation of hetero space charges was observed. However, almost no space charge was observed under AC voltage with the period of less than $1 \mathrm{~min}$. From above results, it was found that a few minutes were required to form the space charge, which origin was residual byproducts generated by the crosslinking reaction.

キーワード： 空間電荷分布, パルス静電応力法, 交流課電, 架橋ポリエチレン

(Space charge distribution, Pulsed electro-acoustic method, AC voltage application, XLPE)

\section{1.はじめに}

架橋ポリエチレン（XLI P E）は電カケーブルの絶縁材 料として用いられているため、高電界下における電気的特 性に関する研究が盛んに行われてきた。特に、空間電荷の 蓄積が絶縁破壊に与える影響が報告[1]されて以来、空間電 荷の形成に関する研究がクローズアップされている。これ までの報告では、X L F E E直流高電界を印加するとバル ク内部に多量の空間電荷が蓄積する[2]が、 $50 \mathrm{~Hz}$ の交流電圧 下では空間電荷の蓄積は観測されていない[3]。これらのこ とから、XLPEに印加する交流電圧の周波数によって空 間電荷形成猧程が異なることが予想される。しかし、印加 電圧の周波数が空間電荷形成に与える影響に関しては報告 例が無い。

そこで今回は、パル人静電応力（P E A）法[4]を用いて、 直流から $50 \mathrm{~Hz}$ までの任意の周波数で交流電圧印加状態に おける空間電荷分布を自動計測するシステムを開発した。 交流課電中の空間電荷分布測定では、交流電圧の位相角に
より電荷分布が変化すると考えられ、任意の位相角に打い て空間電荷分布を測定する必要がある。すなおち、 $0.01 \mathrm{~Hz}$ オーダーの低周波交流課電中に抠ける測定では、变動する 交流電圧に対して 1 秒程度の短い測定時間の実現が要求さ れる。また、 $50 \mathrm{~Hz}$ の交流電圧印加時で、、印加交流電圧の 位相角に同期させて測定を行い加算平均する手法が報告さ れている[3]が、任意の周波数に扔いて測定するためには、 測定のタイミングを印加電圧に対して正確に同期させる計 測システムが必要になる。今回閒発したシステムでは、ノ イズを軽隇させることによりアベレージング回数を減らし、 測定時間を 0.4 秒に短縮した。また、コンピュータの導入に より測定の夕イミングを交流周波数と同時に制御し、任意 の位相角において正確に空間電荷分布が測定できる。ここ では、このシステムを用いて直流から $50 \mathrm{~Hz}$ までの電圧下に 拀いて、XLPE中に形成される空間電荷分布を浿定した 結果を報告する。 


\section{2. 試料および実験装置}

$<2.1>$ 試料試料は架橋壮リエチレンであり、ホット プレスにより厚さ約 $500 \mu \mathrm{m}$ に成型されている。な㧍、今回 の実歌では試料に真空蒸着による電極は付けずに用いた。 これは、架橋ポリエチレン試料中に含まれている架橋分解 残渣等の不純物が、真空蒸着に㧍ける脱気過程によって揮 発することを避け、実際のケーブル絶縁材料に近い状態で 実験に供するためである。

$<2.2>$ 実験装置图 1 は、パルス静電応力法を用いた 空間電荷分布自動計測システムの構成図である。パルス静 電応力法[4]は、試料の厚さ方向の空間電荷分布を非破壊で 定量的に測定する手法である。固体誘電体試料を平行平板 電極で挟み、試料にパル久電界を印加すると、静電応力に より電荷量に比例した大きさのパル久圧力波が空間電荷の 存在する位置で発生する。この圧力波を圧電素子で検出す ることにより、空間電荷分布が測定される。

本システムでは、任意り周波数で交流電圧印加状態にお ける空間電荷分布を位相角に同期させて自動計測するため、 コンピュータにより下記に示す印加電圧や印加パル久電界 の制御、および検出波形の信号処理を行った。

（1）印加電圧の制御コンピュータ・プログラムで作 成された波形データを、デジタル・アナログ変換器で最大 $\pm 10 \mathrm{~V}$ の電圧信号に变換し、これを高電圧增幅器（松定プ
レシジョン製 HEOP-20B1-MK）により 2000 倍（最大士 $20 \mathrm{kV}$ ）に増幅して試料に印加した。これにより、任意の波 形の電圧を正確に試料に印加することができる。

（2）パルス電界の制御上記の印加電圧の制御と同時 にパルス発生器（パルス電圧 $\mathrm{Vp}=2 \mathrm{kV}$ 、パル久幅 $\tau=10 \mathrm{~ns}$ ）を 制御し、交流電圧の位相角とパル久電圧印加の同期を正碓 に行った。

（3）信号処理 コンピュータとデジタルオシロスコ ープ（Lecroy 製 9350A）を（Ｆ－ＩＢケーブル(規格 IEEE-488) で接続し、信号波形の検出、加算平均処理、保存等を自動 的に行わせた。上記の印加電圧およびパル久電圧の制御と 同時にオシロスコープを制御することにより、交流電圧の 位相角と加算平均処理の同期を正確に行った。

以上の改良を施すことにより、パル人発生器のパルス発


測定時間約 0.4 秒、波形デー夕の転送や処理に要する時間も 含めて 1 秒以下 0 時間間隔で、空間電荷分布を交流位相角 に同期させて自動計測するシメテムが実現できた。

\section{3. 実験方法}


であり、周期は $\mathrm{T}=20 \mathrm{~ms}, 0.1,1,10 \mathrm{~s}, 1,4,10,40,80 \mathrm{~min}$ に設定 した。また、測定は交流電圧の 1 周期を 16 分割（位相角 $22.5^{\circ}$ に相当）して行った。パル久電界ひ印加方法は、周期 $\mathrm{T}=20 \mathrm{~ms} \sim 10 \mathrm{~s}$ よ、 $\mathrm{T}=1 \sim 80 \mathrm{~min}$.の場合の2種類に分けた。



図 1 パルス静電応力法による印加電圧・位相可変自動空間電荷分布測定システム

Fig. 1. Schematic diagram of automatic space charge measurement system using PEA method. 
周期 $\mathrm{T}=20 \mathrm{~ms} \sim 10 \mathrm{~s}$ の場合の測定法は、既報[3]に示された 手法と同様である。すなわち、交流電圧の任意の位相角に 同期させてパル久電界を試料に印加し、得られた波形を加 算平均することにより、その位相角に㧍ける空間電荷分布 を求める。この手法を図 2 に示す。

周期 $\mathrm{T}=1 \sim 80 \mathrm{~min}$.の場合には、印加時間が各測定位相角に 達した際にパル久電界を約 $150 \mathrm{~Hz}$ の間隔で連続的に印加し 同期加算平均（最低 64 回）を行う。測定に要する時間は周 期 Tの1\%以下（最低約 0.4s）とした。この場合も図3に 示すように、 1 周期を 16 分割して測定を行った。



图 2 周期 $\mathrm{T}=20 \mathrm{~ms} \sim 10 \mathrm{~s}$ における パル久電压印加タイミング

Fig. 2. Experimental condition for $\mathrm{AC}$ voltage application. Period $\mathrm{T}=20 \mathrm{~ms} \sim 10 \mathrm{~s}$.

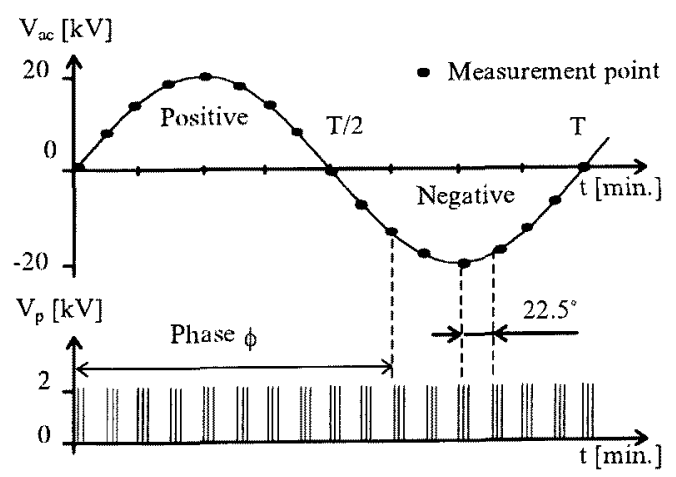

図 3 周期 $\mathrm{T}=1 \sim 80 \mathrm{~min}$ に抢ける パル入電压印加タイミング

Fig. 3. Experimental condition for $\mathrm{AC}$ voltage application. Period T=1 $\sim 80 \mathrm{~min}$.

\section{4. 実験結果および考察}

$<4.1>$ 空間電荷分布測定結果＼cjkstart图4に、架橋ポリエ于 レンに周期 $\mathrm{T}=80 \mathrm{~min}$ の交流電圧を課電中に測定した空間電 荷分布を示す。同図中で、負電荷(1)と正電荷(2)は、印加電 圧と蓄積空間電荷とによる電極誘道電荷である。同図にお
いて、例えば位相角 $\phi=45^{\circ}$ の場合、正電荷(3)上負電荷(4)が それぞれ陰極之陽極の近傍に観察されている。これらの蓄 積電荷はへテロ空間電荷であり、XL P E に含まれる架橋 分解残渣の存在が原因で発生すると推测される[5]。半周期 の正極性電圧印加でこのへテロ電荷け蓄積が観られ、位相 角 $\phi=180^{\circ}$ で電圧極性が反転した植後も、反転前上同極性 の空間電荷が残留した。その後、位相角 $\phi=225^{\circ}$ 近辺で空 問電荷の極性が反転した（負電荷(5)乞正電荷(6)）。すなわ ち、ここで観測されたへテロ空間電荷(3)〜(6)け変化は、印 加交流電界の変動に完全には追随しては㧍らず、数分間の 形成時間を要することを示している。

なお、例えば同図 $\phi=90^{\circ}$ などに执いて陰極近傍にホモ空 間電荷である負電荷(4)’が観測さ机ている。X L P E に $0.8 \mathrm{MV} / \mathrm{cm}$ 以上の直流高電界を印加するとホモ空間電荷であ るいわゆるパケット状空間電荷が発生するとり報告がある $[6,7]$ 。今回の実験ではピーク電界は $0.4 \mathrm{MV} / \mathrm{cm}$ であり、文 献 $[6,7]$ で報告された電界より低い。現段階では、(4)’の架 間電荷がこのパケット状空間電荷と同種のものであるか否 かは検討中である。

次に、图 5 に周期 $\mathrm{T}=1 \mathrm{~min}$ の交流電圧を印加した際の空間 電荷分布を示す。図4 に示した周期 $\mathrm{T}=8(\mathrm{~min} 0)$ 結果と比較 すると、 $\mathrm{T}=1 \mathrm{~min}$ では顕著な空間電荷が観測されていない。 すなわち、 $\mathrm{T}=80 \mathrm{~min}$ で観測されたへテロ空間電荷は、形成に 数分の時間を要するために $\mathrm{T}=1 \min$ り交流電圧下では形成さ れていないことが分かる。

图6には周期 $\mathrm{T}=20 \mathrm{~ms}(f=50 \mathrm{~Hz}) \quad 0$ )交流電圧下に測定さ れた空間電荷分布を示す。この場合は、試料内に空間電荷 がほとんど蓄積していないことが分かる。

\section{$<4.2>$ 空間電荷総量と課電交流位相角との関係}

交流課電中 1 周期目から 3 周期目に測定された空間電荷 分布をもとに、バルク内の正電荷上負電荷り総量を求めた。 图 7 に、XL P E についての空間電荷総量上課電交流電圧 位相角との関倸を示す。 $\mathrm{T}=80 \mathrm{~min}$ および $\mathrm{T}=40 \mathrm{~min}$ の長周期 課電の場合、印加電圧の極性に関倸なくほぼ全位相角にわ たって多量ひ正電荷扩よび負電哬がバルク内に蓄積されて いることが分かる。また、この空間電荷総量は正電荷につ いては $180^{\circ}$ 付近、負電荷では $360^{\circ}$ 付近でそれぞれ周期的 に最低值をとるが、正弦波交流け周期とは完全に一致して おらず、数分の遅れがあることが分かる。このことは、架 橋㓮残渣によるへテロ空間電荷ひ形成、移動には電圧印加 開始から数分の時間が必要なことを示している。 


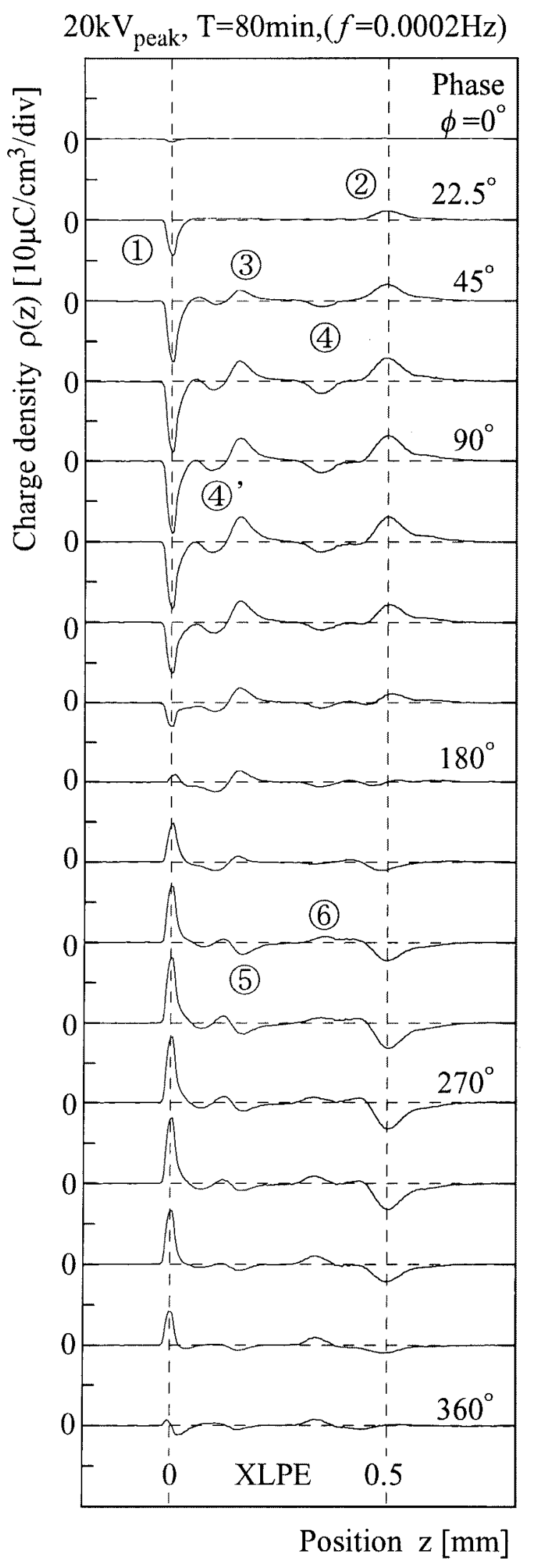

図 4 周期 $80 \mathrm{~min}$ の各位相角における空間電荷分布

Fig. 4. Space charge formation at each phase angle of $\mathrm{AC}$ voltage $(\mathrm{T}=80 \mathrm{~min})$.
$20 \mathrm{kV}_{\text {peak }}, \mathrm{T}=1 \mathrm{~min},(f=0.02 \mathrm{~Hz})$

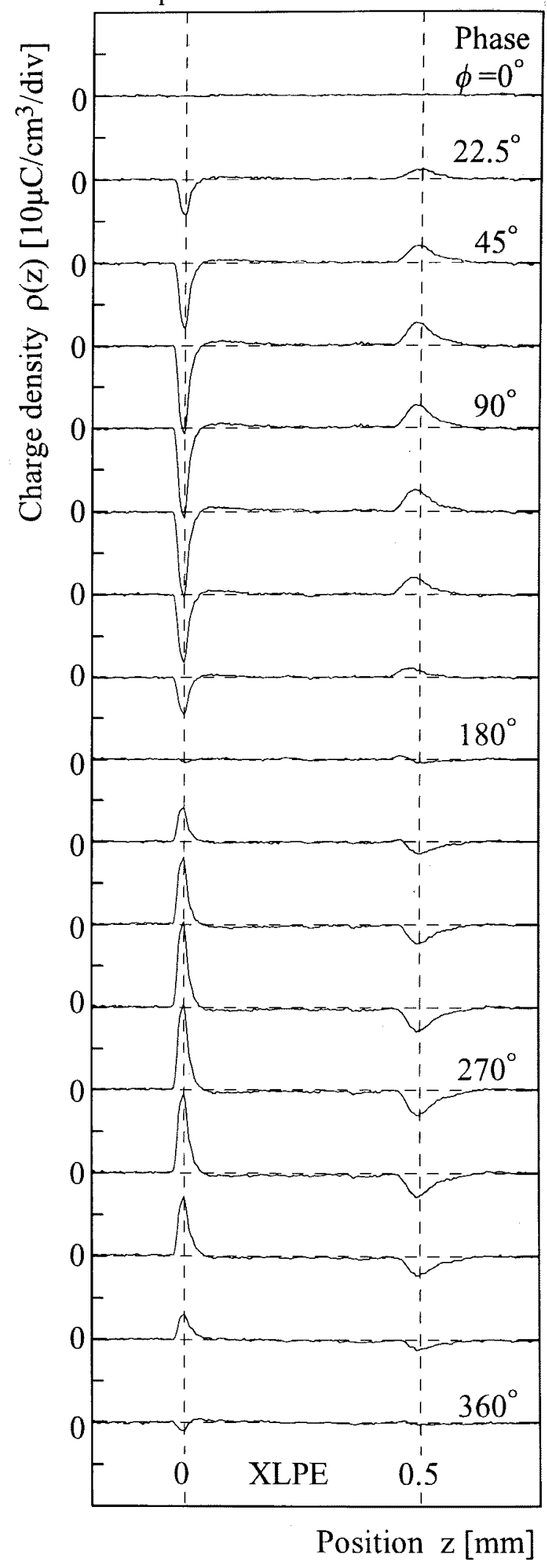

図 5 周期 $1 \min$ の各位相角における空間電荷分布

Fig. 5. Space charge formation at each phase angle of $\mathrm{AC}$ voltage $(\mathrm{T}=1 \mathrm{~min})$. 


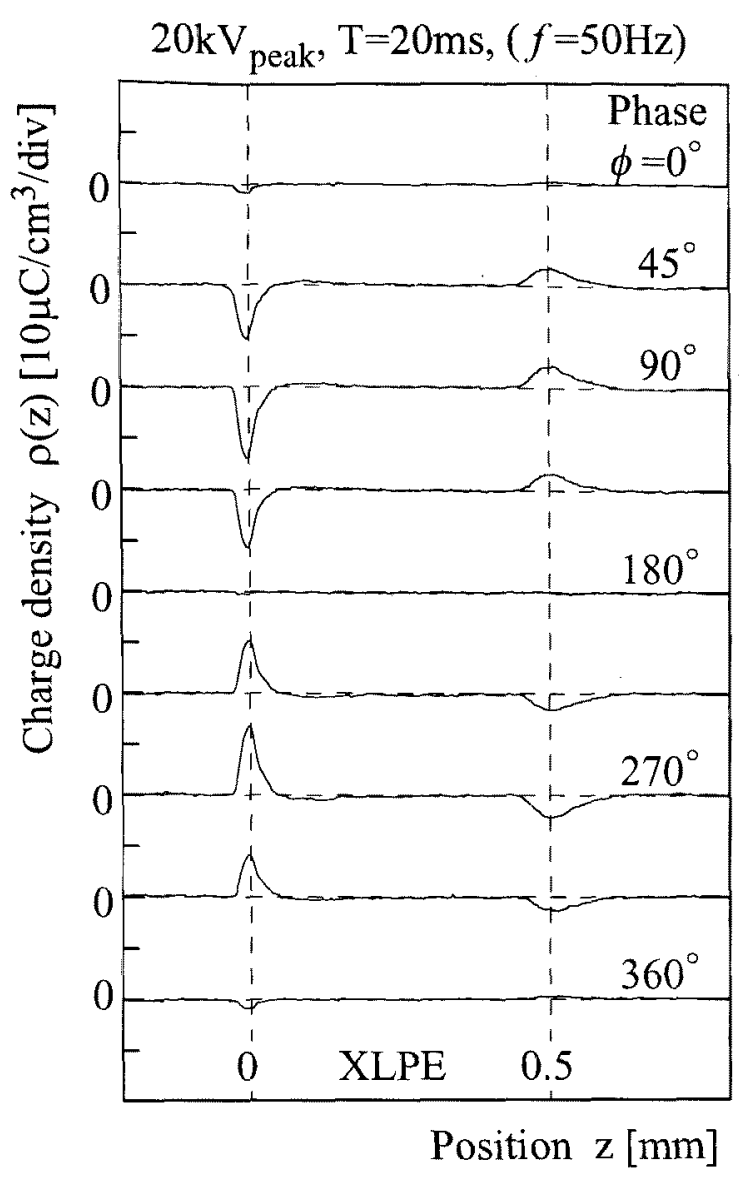

図 6 周波数 $50 \mathrm{~Hz}$ の各位相角における空間電荷分布

Fig. 6. Space charge formation at each phase angle of AC voltage $(T=20 \mathrm{~ms})$.

一方、周期 $\mathrm{T}=1 \mathrm{~min}$ 以下の交流電圧下の場合は、前述したよ うな多量の空間電荷は钼測されていない。これは、印加電 界の变動が架橋分解残椬によるへテロ空間電荷の形成に要 する時間以下であるためであると考えられる。

\section{<4.3> 総空間電荷量と課電交流周波数との関係}

交流電圧印加 1 周期日に得られた各空間電荷総量の平均 值を求め、図 8 に空間電荷総量と課電交流周波数との関係 を示す。交流周期 $\mathrm{T}=40 \sim 80 \mathrm{~min}$ の課電中に観測された空間電 荷総量は、直流電圧 $20 \mathrm{kV}$ 印加時の空間電荷総量と注ぼ同じ 量であることが分かる。この空閒電荷総量は、正負ともに 周期 $\mathrm{T}$ が小さくなるに従って減少し、 $\mathrm{T}=10 \mathrm{~s}$ 以下 $(f=0.1 \mathrm{~Hz}$ 以上）では殆どバルク内に空間電荷が蓄積されなくなる。

\section{5.おわりに}

任意の周波数の交流電压を印加した状態で空間電荷分布 を測定するために、パルス静電応力法を用いて、短時間 (測



図 7 交流課電 $1 \sim 3$ 周期目に打ける空間電荷総量と 電圧位相角の関係

Fig. 7. Phase dependence of total amounts of positive \& negative space charges.

定時間約 0.4 秒) で測定できる自動計測シ久テムを新たに開 発した。またこの装置を使って、周波数 $f=0.0002 \sim 50 \mathrm{~Hz} の$

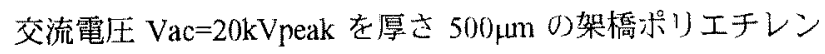
に印加した際の空間電荷分布を調查した結果、以下のよう な結論が得られた。

(1) 直流および $\mathrm{T}=80,40 \mathrm{~min}$ などり長周期の交流電圧を 架橋ポリエチレンに印加すると、多量のへテロ空間電荷が 蓄櫕する。

（2）10秒より短い周期の交流電土を印加した場合は、 試料内にはへテロ空間電荷が蓄積されない。 


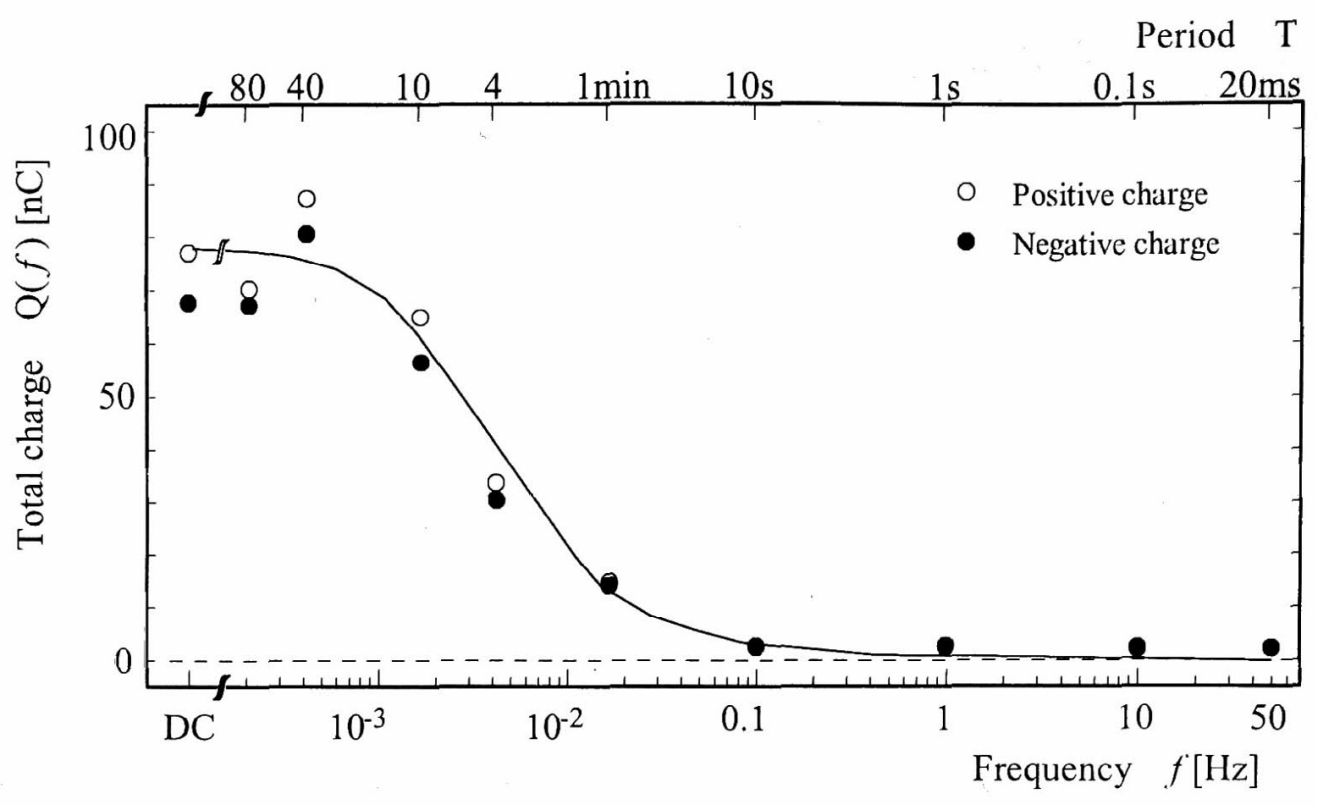

図 8 空間電荷総量と印加交流電圧の周波数との関係

Fig. 8. Relationship between total amounts of positive \& negative space charges and applied frequency.

最後に、本研究を行うにあたり、試料を御提供下さいま した(株) フジクラの宮田裕之氏に感謝の意を表します。

(平成 8 年 1 月 18 日受付, 平成 8 年 6 月 6 日再受付)

\section{文献}

[1] A.Bradwell, et al., "Conduction in polyethylene with strong electric fields and the effect of prestressing on the electric strength", Proc.IEE., Vol.118, pp.247-254, 1971.

[2] Y.Li, et al., "Experimental observation of charge transport and injection in XLPE at polarity reversal", J. Phys. D: Appl. Phys. 25 , pp.704-716, 1992.

[3] R.Liu, et al., "Pulsed electro-acoustic method for measurement of space charge distribution in power cables under both DC and AC electric fields", J. Phys. D: Appl. Phys. 26, pp.986-993, 1993.

[4] Y.Li, et al., "Pulsed Electroacoustic Method for Measurement of Charge Accumulation in Solid Dielectrics", IEEE Trans.on DEI, Vol.1, No.2, pp.188-195, 1994.

[5] 李他, 「X L P E 中の架橋残椬が空間電荷分布形成に及ぼ す影響」, 電学論 A, Vol.112, pp.209-214, (平 2).

[6] N.Hozumi, et al., "Direct Observation of Time-dependent Space Charge Profiles in XLPE Cable under High Electric Field", IEEE Trans. on DEI, Vol.1, pp.1068-1076

[7] H.Kon, et al., "Packet-like Space Charge Behavior and Conduction in Polyethylene for Cable Insulation", Proc.1995 Int'l Symp. on Electr. Insul. Materials, pp.243-246, 1995.

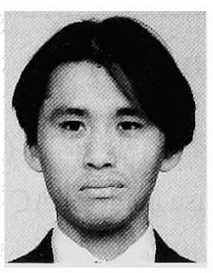

田中康寛（正員）(電学論A、116巻8号、p. 689参照)

高田 達 雄 (正員) (電学論A、116巻8号、p.689参照)

(学生員) 1969年 8 月22日生まれ。 94年3月武蔵工業大学機械工学科卒業。 96 年 3 月武藏工業大学大学院生産機 械工学専攻修士課程修了。同年4月、古 河電気工業（株）入社。現在、千葉 研究所電力シ火テム研究室に勤務。 開発に従事。 主として、高電圧测定シ人テムの研究 